\title{
Repertoire of human gut microbes
}

\author{
Perrine Hugon ${ }^{a}$, Jean-Christophe Lagier ${ }^{b}$, Philippe Colson ${ }^{b}$, Fadi Bittar ${ }^{b}$, \\ Didier Raoult ${ }^{\text {b, c, * }}$
}

\begin{abstract}
a Institut Pasteur, Unité de Biologie des Spirochètes, Paris, France
b Aix-Marseille Université URMITE, UM63, CNRS 7278, IRD 198, INSERM 1095, 27 Boulevard Jean Moulin, 13385, Marseille Cedex 5, France c Special Infectious Agents Unit, King Fahd Medical Research Center, King Abdulaziz University, Jeddah, 21589, Saudi Arabia
\end{abstract}

\footnotetext{
* Corresponding author. Aix-Marseille Université, URMITE - UMR 63, CNRS 7278, IRD 198, INSERM 1095, Faculté de Médecine, 27 Bd Jean Moulin, 13005, Marseille, France.

E-mail address: didier.raoult@gmail.com (D. Raoult).
}

In 1675, Antoni Van Leeuwenhoeck was the first to observe several forms using an optical microscope that he named "animalcules", realizing later that these were microorganisms. The first classification of living organisms proposed by Ehrenberg in 1833 was based on what we could visualize. The failure of this kind of classification arises from viral culture, which preceded direct observations that were finally achieved during the 20th century by electron microscopy.

The number of prokaryotic species is estimated at approximately 10 million, although only 1800 were known in 1980, and 14,000 to date, thanks to the advent of 16S rRNA amplification and sequencing. This highlights our inability to access the entire diversity. Indeed, a large number of bacteria are only, known as Operational Taxonomic Units (OTUs) and detected as a result of metagenomics studies, revealing an unexplored world known as the "dark matter". Recently, the rebirth of bacterial culture through the example of culturomics has dramatically increased the human gut repertoire as well as the 18SrRNA sequencing allowed to largely extend the repertoire of Eukaryotes. Finally, filtration and co-culture on free-living protists associated with high-throughput culture elucidated a part of the megavirome.

While the majority of studies currently performed on the human gut microbiota focus on bacterial diversity, it appears that several other prokaryotes (including archaea) and eukaryotic populations also inhabit this ecosystem; their detection depending exclusively on the tools used. Rational and comprehensive establishment of this ecosystem will allow the understanding of human health associated with gut microbiota and the potential to change this. 


\section{Introduction}

The exploration of the human gut microbiota has exploded during the last decade. With the tremendous changes in molecular technologies and the new "omics" strategies developed, this ecosystem is now considered for its role in metabolism, immune system and human health [1]. Moreover, numerous metagenomic studies performed during the last years have suggested an association between the microbial composition of the human gut and various diseases including for instance obesity [2], Crohn's disease [3], or irritable bowel syndrome [4]. The gut microbiota harbours at least $10^{11}$ to $10^{12}$ bacteria per gram of faeces [5], and its composition varies with physiological factors [6] such as geographic provenance, age, dietary habits, malnutrition, and external factors can also imbalance the microbiota as probiotics or antimicrobial agents uses [7]. The relationship between the host and this complex ecosystem composed by prokaryotes, viruses, fungi and parasites is extremely complex. Recent significant efforts have been deployed to characterize the gut repertoire; however there is still a need to provide an efficient repertoire even for all microorganisms isolated or detected in the human gut [8]. Regarding viruses, giant ones have been recently showed being genuine members of the tree of life $[9,10]$. Thus, their tremendous gene repertoires contain genes with homologs in cellular organisms, among which those encoding DNA-dependent RNA polymerase. This represents a change of paradigm. Indeed, the predominant use of ribosomal genes to classify organisms that was introduced in the 1970s by C. Woese, who defined three domains of life, namely Bacteria, Archea and Eukarya, led to exclude viruses because they are devoid of such genes [11]. Apart from lacking ribosomes, giant viruses share many features with other intracellular microorganisms and can be considered as microbes. This led to propose in 2013 a new classification of microbes in four 'TRUC', an acronym for Things Resisting Uncompleted Classifications, that does not rely on ribosomal genes but takes into account giant viruses alongside with bacteria, archaea and eukaryotic microbes and should allow more comprehensive description of human gut microbiota [10]. In this review we are focusing on human gut components of the bacterial, fungal, parasites and archaeal diversity, as well as on the gut virome discovery.

\section{The prokaryotes}

\subsection{Culture-based methods as the pioneer strategy for human gut} microbiota research

The first discrepancy arose from initial culture studies [5]. At that time, the 1970s, gram-staining and microscopic examination performed directly on stool samples were the techniques used to study gut microbiota composition [12-14]. While such techniques revealed the predominance of gram-negative bacteria in stool samples [12], culture counts identified a majority of gram-positive bacteria [14] and anaerobes dominated the community. The second discrepancy was named few years later by Staley and Konopka as the "great plate count anomaly" [15]. It was the difference between "what we can see" on direct microscopic observation and "what's growing in our plate". This was indeed confirmed 20 years later as only $1 \%$ of bacteria can be easily grown in vitro [16].

Anaerobes were considered to be the major component of gut microflora [13], however this seems biased as a great majority of studies concentrated their efforts on these specific bacteria [5]. In 1969, Hungate revolutionized the anaerobic culture in developing the roll tube technique [17], thus allowing isolation of extremely oxygen-sensitive (EOS) bacteria. Several species (within genera Bacteroides, Clostridium, Veillonella, Ruminococcus, Eubacterium, Bifidobacterium, Lactobacillus, Fusobacterium, Peptococcus and Peptostreptococcus) were considered to dominate the gut microbiota. Finally, before molecular tools were incorporated, it was estimated that 400-500 different species composed the gut microflora $[13,18]$, which remained partially characterized due to the technical limitations.

\subsection{The molecular revolution: how improved technologies enhanced our knowledge of prokaryotic diversity}

Introduced fifteen years ago, 16S rDNA sequence analysis is still the basic tool for studying bacterial taxonomy and phylogenic relationships between microorganisms. In the 2000s, the introduction of high-throughput sequencing techniques based on the amplification of the 16S rRNA gene improved understanding of bacterial diversity from complex microbiota, and demonstrated that $80 \%$ of bacteria detected with molecular tools were uncultured [5]. However, it is important to understand the biases and limitations of 16S rRNA gene profiling. Firstly, 16S rRNA gene lacks sensitivity within specific genera and cannot delineate between two species with high interspecies similarity [19]. Secondly, gene sequence heterogeneity can be encountered in species having more than one copy [20]. Regarding DNA extraction kits [21,22], the hypervariable region targeted in 16S rRNA gene and primer choices [23], the depth bias [24], several studies reported the serious impact on the microbiota abundance and diversity these factors could play. More recently, a study performed on 16 stool samples revealed that pyrosequencing performed on the V6 region on $16 \mathrm{~S}$ rRNA gene has neglected some of the gram-negative bacteria detected using transmission electron microscopy [25].

Regarding prokaryotic diversity in humans, more than 120 different prokaryotic phyla have been identified and only 31 phyla included cultured species [8]. Moreover, 12 bacterial phyla with cultured representatives have been recorded in humans (Firmicutes, Bacteroidetes, Actinobacteria, Proteobacteria, Chlamydiae, Deinococcus-Thermus, Fusobacteria, Tenericutes, Lentisphaerae, Spirochaetes, Synergistetes and Verrucomicrobia) (Fig. 1, Table 1) [8], where each phylum represents species that have also been isolated in the human gut. Moreover, the majority of species isolated in the gut belong to four phyla, Firmicutes, Proteobacteria, Actinobacteria and Bacteroidetes and dominant species from the families Bacillaceae, Enterobacteriaceae, Corynebacteriaceae and Bacteroidaceae respectively [8]. In addition to cultured bacteria, several phyla have only been detected in the gut and remain as yet uncultured [26]: species belonging to TM7 have been detected in both healthy persons and patients suffering from inflammatory bowel disease [27]; Melainabacteria, a new candidate phylum sibling to Cyanobacteria [28], and the Gemmatimonadetes phylum [26].

High-throughput sequencing studies performed the last ten years [29-33] showed a majority of reads belonging to two dominant phyla (Firmicutes and Bacteroides), corresponding to species belonging to the Ruminococcaceae, Clostridiaceae, Lachnospiraceae, Bacteroidaceae families that contain a majority of 


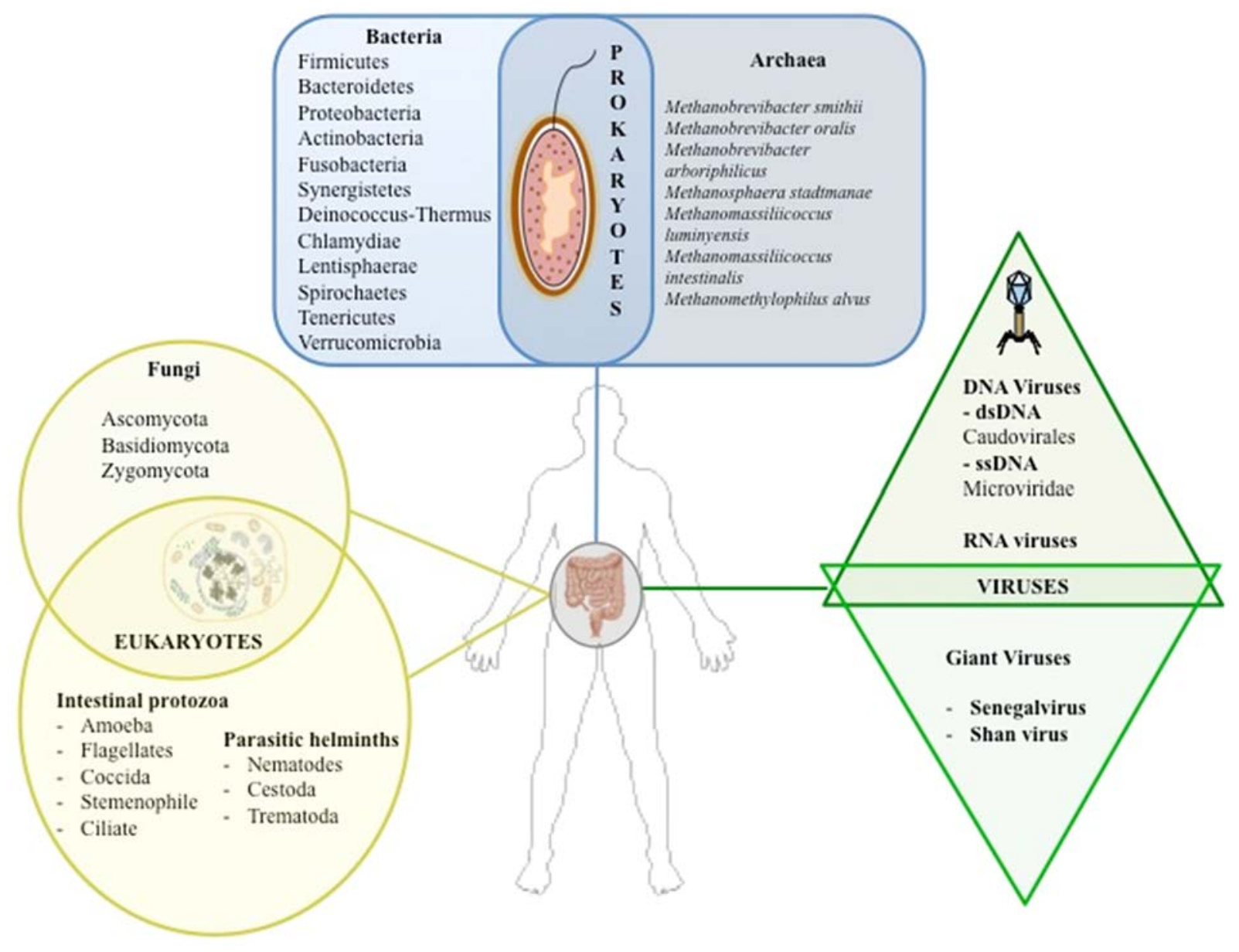

Fig. 1. Diversity of Prokaryotes, Eukaryotes and viruses in the human gut microbiota.

anaerobic species as yet uncultured. Moreover, several members of Lachnospiraceae family (Eubacterium spp., Anaerostipes spp., Roseburia spp., Coprococcus spp. for example) are butyrate-producing bacteria that are difficult to cultivate from faecal samples [34,35]. Butyrate-producing bacteria have recently been associated with health status in several diseases [36-38] as anti-inflammatory and anticarcinogenic properties have been identified [39]. These discrepancies between molecular and culture-dependant studies emphasize the need to improve the anaerobic culture to understand the specific role these species are playing in the human gut microbiota. Finally, species belonging to the highly diverse Proteobacteria phylum are commonly detected in molecular studies [26]. Due to the specific primers the phylum Actinobacteria needs to be amplified [40] and it often remains underrepresented by large sequencing studies [26], whereas its species are easily cultivated.

\subsection{Culturomics: a third shift in understanding gut microbiota?}

Matrix-assisted laser desorption/ionization-time of flight mass spectrometry (MALDI-TOF-MS) has emerged as a time- and costeffective method for the identification of bacteria [41]. This efficient identification method has been the main key to developing high-throughput culture-dependent studies. Indeed, since 1995 with the development of culture-independent methods, notably 16S rRNA amplification and sequencing and more recently metagenomics studies, bacterial culture was considered as outdated. In the last four years, a new strategy named "culturomics" was developed to study the human gut microbiota [24]. This method is based on the diversification of culture conditions (by varying atmosphere, temperature, incubation time, passive and active filtration or antibiotics in order to culture the minority populations) with the objective of mimicking the natural conditions within the digestive tract, using notably rumen fluid [24,42].

In their pioneering study, Lagier et al., using 212 culture conditions, testing 32,500 colonies by MALDI-TOF, identified 340 bacterial species, including 31 putative new species [24]. In addition, they demonstrated the complementarity of metagenomics and culturomics because only $15 \%$ of the bacterial species were concomitantly detected. A stringent analysis of the culture conditions tested in the first study showed that all the bacteria identified were cultured by testing 70 culture conditions [24]. These 70 culture conditions were applied for the study of supplementary stool samples from other patient populations such as those treated with antibiotics, suffering from anorexia nervosa or obesity, and healthy subjects from various geographic areas, extending the repertoire [24,42-45]. For the ongoing studies we selected 18 different culture conditions in liquid media with subcultures on solid media every 3 days [42]. This resulted in culturing 717 bacterial species from 7 phyla (Actinobacteria, Bacteroidetes, Deinococcus-Thermus, Firmicutes, Fusobacteria, Proteobacteria, Synergistetes) including several new bacterial species [42]. In order to describe these new isolates, we developed a polyphasic strategy combining phenotypic and genotypic characteristics obtainable and comparable by most laboratories, and named taxono-genomics [46]. The genome 
Table 1

Prokaryotes cultivated in the human gut microbiota.

\begin{tabular}{|c|c|}
\hline Phylum & Family \\
\hline Actinobacteria & $\begin{array}{l}\text { Actinomycetaceae } \\
\text { Bifidobacteriaceae } \\
\text { Bogoriellaceae } \\
\text { Brevibacteriaceae } \\
\text { Cellulomonadaceae } \\
\text { Coriobacteriaceae } \\
\text { Corynebacteriaceae } \\
\text { Dermabacteraceae } \\
\text { Dermacoccaceae } \\
\text { Dermatophilaceae } \\
\text { Dietziaceae } \\
\text { Geodermatophilaceae } \\
\text { Gordoniaceae } \\
\text { Intrasporangiaceae } \\
\text { Microbacteriaceae } \\
\text { Micrococcaceae } \\
\text { Micromonosporaceae } \\
\text { Mycobacteriaceae } \\
\text { Nocardiaceae } \\
\text { Nocardioidaceae } \\
\text { Promicromonosporaceae } \\
\text { Propionibacteriaceae } \\
\text { Streptomycetaceae }\end{array}$ \\
\hline Bacteroidetes & $\begin{array}{l}\text { Bacteroidaceae } \\
\text { Flavobacteriaceae } \\
\text { Porphyromonadaceae } \\
\text { Prevotellaceae } \\
\text { Rikenellaceae } \\
\text { Sphingobacteriaceae }\end{array}$ \\
\hline Firmicutes & $\begin{array}{l}\text { Acidaminococcaceae } \\
\text { Aerococcaceae } \\
\text { Bacillaceae } \\
\text { Carnobacteriaceae } \\
\text { Catabacteriaceae } \\
\text { Christensenellaceae } \\
\text { Clostridiaceae } \\
\text { Clostridiales } \\
\text { Enterococcaceae } \\
\text { Erysipelotrichaceae } \\
\text { Eubacteriaceae } \\
\text { Lachnospiraceae } \\
\text { Lactobacillaceae } \\
\text { Leuconostocaceae } \\
\text { Listeriaceae } \\
\text { Paenibacillaceae } \\
\text { Peptococcaceae } \\
\text { Peptostreptococcaceae } \\
\text { Planococcaceae } \\
\text { Ruminococcaceae } \\
\text { Staphylococcaceae } \\
\text { Streptococcaceae } \\
\text { Thermoactinomycetaceae } \\
\text { Veillonellaceae }\end{array}$ \\
\hline Proteobacteria & $\begin{array}{l}\text { Acetobacteraceae } \\
\text { Aeromonadaceae } \\
\text { Alcaligenaceae } \\
\text { Brucellaceae } \\
\text { Burkholderiaceae } \\
\text { Campylobacteraceae } \\
\text { Caulobacteraceae } \\
\text { Chromobacteriaceae } \\
\text { Comamonadaceae } \\
\text { Desulfovibrionaceae } \\
\text { Enterobacteriaceae } \\
\text { Francisellaceae } \\
\text { Halomonadaceae } \\
\text { Helicobacteraceae } \\
\text { Legionellaceae } \\
\text { Methylobacteriaceae } \\
\text { Moraxellaceae } \\
\text { Neisseriaceae } \\
\text { Oxalobacteraceae } \\
\text { Pasteurellaceae } \\
\text { Pseudomonadaceae }\end{array}$ \\
\hline
\end{tabular}

Table 1 (continued)

\begin{tabular}{ll}
\hline Phylum & Family \\
\hline & Rhizobiaceae \\
& Rhodobacteraceae \\
Salinisphaeraceae & Shewanellaceae \\
& Sphingomonadaceae \\
& Succinivibrionaceae \\
& Sutterellaceae \\
& Vibrionaceae \\
& Xanthobacteraceae \\
Chlamydiae & Xanthomonadaceae \\
Deinococcus-Thermus & Chlamydiaceae \\
Fusobacteria & Deinococcaceae \\
Lentisphaerae & Fusobacteriaceae \\
Spirochaetes & Victivallaceae \\
& Brachyspiraceae \\
Synergistetes & Leptospiraceae \\
Tenericutes & Synergistaceae \\
Verrucomicrobia & Mycoplasmataceae \\
Euryarchaeota & Verrucomicrobiaceae \\
& Halobacteriaceae \\
\hline
\end{tabular}

sequencing and the MALDI-TOF spectra of the new bacterial species were systematically included. In addition, we determined the Average Genomic Identity of Orthologous gene Sequences (AGIOS) of studied strains by comparison with their closest phylogenetic species. To date, we have described 13 bacterial species using taxono-genomics (Aeromicrobium massiliense sp. nov., Alistipes timonensis sp. nov., Anaerococcus senegalensis sp. nov., Brevibacillus massiliensis sp. nov., Brevibacterium senegalense sp. nov., Enterobacter massiliensis sp. nov., Herbaspirillum massiliense sp. nov. Kurthia massiliensis, Senegalimassilia anaerobia gen. nov., sp. nov., Paenibacillus senegalensis, Cellulomonas massiliensis, Peptoniphilus timonensis, and Clostridium senegalense). These have officially been recognized as new genera and/or species in validation lists no. 153 [47], no. 155 [48] and no. 165 [49]. By concomitantly using culturomics, 16S rRNA and MALDI-TOF-MS, the number of bacterial species cultured in clinical microbiology has dramatically increased [42].

\section{The archaeal diversity}

The Archaea community constitutes the third domain of life, separate from bacteria and eukaryote kingdoms [50], although archaea share many characteristics with both bacteria and eukaryotes [51]. Extremophile species, which live in extreme environments under high salt concentrations and extreme $\mathrm{pH}$ and temperatures, were the first to be discovered in the late 1970s [52]. However, we now know that archaeal mesophilic species also represents a large part of the diversity and inhabit non-extreme environments [53]. Moreover, the human gut microbiota include non-methanogenic and methanogenic species, with the latter representing up to $10^{10}$ cells per gram of faeces [54] and having a significant role in the gut microbiota ecosystem through methane production during anaerobic fermentations [55].

In total, eight archaeal species have been isolated in the human gut microbiota [26], all of which belong to the Euryarchaeota phylum (Fig. 1). Methanobrevibacter ruminantium [56] was the first species isolated from stool samples. This was probably a misidentification [26] as Methanobrevibacter smithii dominates in the human gut [57]. The atypical methanogenic Methanosphaera stadtmanae reduces the methanol [58] as does Methanomassiliicoccus luminyensis, discovered more recently, but is phylogenetically distant from $M$ stadtmanae [59]. 
Methanobrevibacter oralis was first isolated in the 1990s from human subgingival plaque [60]. Its genome was only sequenced recently from a stool sample strain [61]. Methanomethylophilus alvus [62] and Methanomassiliicoccus intestinalis [63], two species phylogenetically related to the Thermoplasmatales, were isolated and their genomes sequenced, highlighting a new order named Methanomassiliicoccales shared with M luminyensis [55]. Very recently, Methanobrevibacter arboriphilicus has been isolated from the human gut [64]. Surprisingly it showed the lowest GC content in archaeal species [64].

Additionally, substantial diversity of archaeal species have been detected in the human gut microbiota $[26,55]$ using 16 S rRNA, mcrA or amoA gene sequences [55]. Two halophilic bacteria belonging to the Euryarchaeota phylum were detected in 2008 using the denaturing gradient gel electrophoresis (DGGE) [65] method, and several archaeal representatives associated with the human gut microbiota belonging to Sulfolobales, Nitrososphaerales, Methanosarcinales, Methanomicrobiales were identified [55].

\section{The existence of a human gut microbial virome}

By contrast with the bacterial microbiota, only a few studies have explored the "human gut virome", which represents a fairly new concept $[66,67]$. This appears paradoxical, as the existence of pathogenic viruses was discovered in human faeces a long time ago [68]. Studying viral diversity in the gut appears more difficult than for cellular organisms because they are, for most of them, not visible under a light microscope, and they are devoid of any conserved gene that is shared by all of them (that may be an equivalent to $16 \mathrm{~S}-18 \mathrm{~S}$ rRNA in cells) [69]. Thus, viruses have been sought in the human gut using cell culture, electron microscopy, PCR and finally metagenomics [67]. In current technology advances, high-throughput sequencing highlighted groups of viruses (or Virus Like Particle (VLPs)) associated with the human gut microbiota [70], equivalent to $10^{9}$ VLPs per gram of faeces [71]. Both DNA and RNA viruses were investigated in human stools by metagenomics, from its very onset $[66,72]$. Recent work on the viral community provided a better understanding of the role viruses from the gut could play in its host $[73,74]$, how it could interact with the complex gut ecosystem to influence food digestion [75], and also how it could actively participate in human health through the prevention of invasion by pathogens $[67,76]$.

New sequencing strategies have shown that the gut virome was composed of both eukaryotic viruses and prokaryotic viruses (i.e. viruses that infect bacteria, known as bacteriophages), and that the latter dominate this virus community (Fig. 1) [67,75]. Tailed bacteriophages with double-stranded DNA (dsDNA) that belong to the order Caudovirales appear to be the most abundant in the gut with the single-strand DNA (ssDNA) bacteriophages belonging to the family Microviridae (Fig. 1) [70]. Many DNA or RNA viruses, including rotaviruses, caliciviruses, astroviruses or adenoviruses, have been associated with gastroenteritis [77]. In addition, several human viral pathogens such as enteroviruses, as well as viruses that are transmitted via the faecal-oral route and are excreted by the gut, including, for instance, hepatitis A and E viruses, can be found in stools. Many viruses were unexpectedly identified in human stools. This was also the case for plant viruses, among which Pepper mild mottle virus was found at the greatest titre, estimated to be up to $10^{9}$ per gram of dried faeces, and whose presence seems to be directly correlated with ingested food [72]. These findings suggest that viral diversity in the gut is probably still largely untapped. Surprisingly, bacteriophages residing in the human gut have been estimated at having a titre of the same order of magnitude as that of their bacterial hosts (ratio 1:1) [67,74]. In contrast, in many habitats, oceans for example, bacteriophages are 10 -fold more abundant than their bacterial hosts (ratio 10:1) [75,78]. This could reflect the temperate lifestyle bacteriophages may adopt in the human gut, contrasting with the "kill the winner strategy" they use in marine habitats [75].

In the same way as for the gut microbiota community, our knowledge on viruses from the gut comes from evolving technologies, bearing in mind than each method provides benefits and has limitations [67]: culture-based techniques (phage isolation) and microscopic observations (TEM or fluorescence) were the first methods used, whereas PCR testing and Sanger sequencing form the current majority, and an increasing number of investigations conducted apply high-throughput sequencing to metagenomics [67]. Recently, the CRISPR (Cluster Regularly Interspaced Short Palindromic Repeats)/Cas system was exploited to target phage sequences in the gut microbiome in order to discover new phages associated with the human body; this shed lights on a common phage reservoir associated with the human gut microbiome. Thus, bacteriophage searches have opened a new field of interest and potential applications in therapeutics, diagnostics and biotechnology $[67,79]$.

Giant viruses of amoebas have been discovered over the 12 last years, the first representative being Mimivirus [10,80]. To date, six new or putative viral families have been uncovered, which have been linked by phylogenomics to other double-stranded DNA viruses, including poxiviruses, asfarviruses, irido-/ascoviruses, or phycodnaviruses $[81,82]$. These giant viruses were shown to be ubiquitous worldwide and common in the human environment, primarily water and soil [83]. Unlike other viruses, giant viruses are visible under a light microscope [84]. The size of giant virions is indeed similar to that of small parasitic prokaryotes. In addition, their genome is as large as those of these intracellular microorganisms and comprises a tremendous and unique gene repertoire among viruses. Therefore, they can be considered as microbes [11]. Most of these viruses have been isolated using co-culture on freeliving amoebas from the genera Acanthamoeba [83]. Their detection as part of the virome has long been neglected due to their giant size, as samples were usually filtered prior to analysis to separate viruses from cellular organisms; through this procedure, giant viruses, in contrast with the majority of viruses, are not filtered and remain within the cellular fraction [85].

The first giant virus of amoeba isolated from the human gut, in 2012, was from the stools of a young healthy Senegalese man $[24,85]$. This was a serendipitous discovery as amoebal co-culture of this virus, which was named Senegalvirus, was triggered by the detection in the faeces of reads matching Marseillevirus, the prototype member of the second giant virus family identified [86]. In 2013, a second giant virus that is a close relative of Mimivirus named Shan virus, was isolated from the faeces of a Tunisian patient with pneumonia [87]. This strengthens the interest in expanding our knowledge of giant virus diversity and prevalence in human stools. Moreover, metagenomic reads generated from human stools were identified as matching sequences from virophages, which infect mimiviruses and were discovered in 2008 as the first viruses of viruses $[88,89]$.

\section{Eukaryotes}

Research on this subdominant gut component is fairly recent, as evidenced by the first molecular study published in 2008 [90]. Eukaryotes, defined by the presence of a nucleus and organelles, represent the third domain of life besides Bacteria and Archaea [91]. The taxonomy of human gut eukaryotes is highly complex [91,92] and highlights five major groups (Amoebozoa, Opisthokonta, Excavata, Sar and Archaeplastida) based on recent molecular phylogenetic classification [92]. Fungal species including yeasts and 
filamentous fungi are the most abundant group of eukaryotes in the human gut. However parasites, including unicellular organisms (protozoa) and multicellular species (helminths) (Fig. 1), could also be present in the human gut but in lower numbers. Their presence is mostly known to have a pathogenic consequence to the host [26].

\subsection{Fungal diversity}

Studying the human gut mycobiome consists of studying how the entire fungal community inhabits the human gastrointestinal tract. Very few studies have focused on the fungal diversity, however recent technological advances can provide deep understanding on this neglected component [93]. Both filamentous fungi and yeasts are cultivated on different solid media, and the majority of them can be identified using MALDI-TOF mass spectrometry $[94,95]$. As for bacteria, MALDI-TOF mass spectrometry has revolutionized the diagnosis of fungal infection in mycology laboratories, allowing both rapid and accurate identification [96]. New culture-independent methods, which remain under-developed for fungal population [97], are targeting mainly the Internal Transcribed Spacer ITS1 and ITS2 [91]. This region (i.e. ITS) appears to be more appropriate than $18 \mathrm{~S}$ rDNA for analysing fungal population at the level of clades and species thanks to its high sequence variability [91]. However, many difficulties arise during fungal metagenomic analyses including the low presence of fungal species in the complex biota of the human intestinal tract, requiring the application of ultra-deep sequencing strategy, and the absence of a well established fungal ITS database [97].

The human gut mycobiome displays a very small fungal community divided into three major phyla (Ascomycota 63\%, Basidiomycota 32\%, Zygomycota 3\%) [26], including 273 different species from more than 140 genera [91,93] (Table 2). Recently, a fourth phylum named Microsporidia has been reclassified as fungi [98]. It contains members associated with intestinal diseases [98] including Encephalitozoon hellem, Encephalitozoon intestinalis, Enterocytozoon bieuneusi and Enterocytozoon hellem. Regarding the actual fungal repertoire, 216 different species were detected by molecular tools, 86 species were isolated by culture methods and 29 species were identified using both approaches [91,93]. Among the yeast community, Candida spp. is the most abundant species [26] and Candida albicans and Crugosa rugosa are in their natural environment. However, they can become pathogens and induce candidiasis under specific circumstances [26].

Additionally, Saccharomyces cerevisiae and Galactomyces geotrichum [90] are two yeasts detected frequently in human faecal samples. The second has been cultivated recently from two different stool samples $[99,100]$. Evidence has shown that many fungal species are directly associated with food ingestion prior to sampling. This may explain the presence of G. geotrichum and $S$. cerevisiae in human stools due to their use in food production [26]. However, determining the role fungi play in digestion remains to be illustrated. Finally, several filamentous species belonging to Penicillium and Aspergillus genera have been detected [90] and cultured more recently [99,101]. It is likely that these fungi could represent food contamination, or could just come from food ingestion [26]. Although they have been found in many studies $[18,99,102]$, it is not certain that they play any significant role in the human gut microbiota.

\subsection{Other eukaryote diversity}

More than 50 helminthic genera (complex and multicellular organisms) belonging to nematodes, trematoda and cestoda groups are known to parasitize the human gut [103] and cause infections in millions of people worldwide. In addition, 15 different commensal
Table 2

Eukaryotes cultivated in the human gut microbiota.

\begin{tabular}{|c|c|c|}
\hline Taxa & & Species \\
\hline Fungi & Ascomycota & $\begin{array}{l}\text { Acremonium falciforme } \\
\text { Acremonium strictum } \\
\text { Aspergilluis niger } \\
\text { Aspergillus flavipes } \\
\text { Aspergillus flavus } \\
\text { Aspergillus fumigatus } \\
\text { Aspergillus ruber } \\
\text { Aspergillus spp. } \\
\text { Aspergillus sydowii } \\
\text { Aspergillus versicolor } \\
\text { Beauveria bassiana } \\
\text { Blastoschizomyces capitatus } \\
\text { Candida albicans } \\
\text { Candida famata } \\
\text { Candida glabrata } \\
\text { Candida guilliermondii } \\
\text { Candida kefyr } \\
\text { Candida krusei } \\
\text { Candida lambica } \\
\text { Candida lusitaniae } \\
\text { Candida norvogensis } \\
\text { Candida parapsilosis } \\
\text { Candida pararugosa } \\
\text { Candida rugosa } \\
\text { Candida sp. } \\
\text { Candida sphaerica } \\
\text { Candida tropicalis } \\
\text { Candida utilis } \\
\text { Candida zeynaloides } \\
\text { Cladosporidium bruhnei } \\
\text { Cladosporium spp. } \\
\text { Clavispsora lusitaniae } \\
\text { Davidiella sp. } \\
\text { Davidiella tassiana } \\
\text { Debaryomyces hansenii } \\
\text { Fusarium sp. } \\
\text { Galactomyces candidum } \\
\text { Galactomyces geotrichum } \\
\text { Geothricum spp. } \\
\text { Geotrichum candida } \\
\text { Geotrichum candidum } \\
\text { Hansenula anomala } \\
\text { Hypocrea lixii } \\
\text { Isaria farinosa } \\
\text { Kluyveromyces marxianus } \\
\text { Penicillium allii } \\
\text { Penicillium brevicompactum } \\
\text { Penicillium camemberti } \\
\text { Penicillium citrinum } \\
\text { Penicillium decumbens } \\
\text { Penicillium dipodomyicola } \\
\text { Penicillium marneffei } \\
\text { Penicillium notatum } \\
\text { Penicillium solitum } \\
\text { Penicilliumn steckii } \\
\text { Saccharomyces cerevisiae } \\
\text { Torulaspora delbrueckii } \\
\text { Yarrowia lipolytica } \\
\text { Zygosaccharomyces bisporus }\end{array}$ \\
\hline Fungi & Basidiomycota & $\begin{array}{l}\text { Climacocystis sp. } \\
\text { Cryptococcus albidus } \\
\text { Cryptococcus luteolus } \\
\text { Cryptococcus spp. } \\
\text { Cystofilobasidium capitatum } \\
\text { Exophiala dermatitidis } \\
\text { Malassezia globosa } \\
\text { Malassezia pachydermatis } \\
\text { Malassezia restricta } \\
\text { Malassezia sp. } \\
\text { Pityrosporum sp. } \\
\text { Rhodotorula glutinis } \\
\text { Rhodotorula rubra }\end{array}$ \\
\hline
\end{tabular}


Table 2 (continued)

\begin{tabular}{|c|c|c|}
\hline \multicolumn{2}{|l|}{ Taxa } & Species \\
\hline \multirow{8}{*}{ Fungi } & \multirow{8}{*}{ Zygomycota } & Rhodotorula sp. \\
\hline & & Trichosporon asahii \\
\hline & & Trichosporon beigelii \\
\hline & & Trichosporon spp. \\
\hline & & Basidiobolus ranarum \\
\hline & & Mucor racemosus \\
\hline & & Mucor spp. \\
\hline & & Rhizopus spp. \\
\hline \multirow[t]{3}{*}{ Helminths } & \multirow[t]{3}{*}{ Nematodes } & Ancylostoma duedonale \\
\hline & & Necator americanus \\
\hline & & Strongyloides stercoralis \\
\hline \multirow[t]{5}{*}{ Protozoa } & \multirow[t]{5}{*}{ Amoebozoa } & Endolimax nana \\
\hline & & Entamoeba coli \\
\hline & & Entamoeba dispar \\
\hline & & Entamoeba histolytica \\
\hline & & Iodamoeba bütschlii \\
\hline \multirow[t]{2}{*}{ Protozoa } & \multirow[t]{2}{*}{ Parabasalia } & Dientamoeba fragilis \\
\hline & & Pentatrichomonas hominis \\
\hline Protozoa & Stemenopile & Blastocystis hominis \\
\hline
\end{tabular}

or parasitic protozoa genera [91] have also been described. Only a few of intestinal protozoa (defined as unicellular eukaryotes) playing a role in disease in humans, while the majority of protozoa exhibit a free-living lifestyle in water and soil environments [91]. Giardia intestinalis (flagellates), Cryptosporidium parvum, Cyclospora cayetanensis and Isospora belli (Coccidia), Blastocystis sp. (stemenopile), Entamoeba histolytica (Amoeba) and Balantidium coli (ciliates) are the most abundant protozoa parasitizing the human gut through a cyst and trophozoite life cycle [91] (Table 2).

Despite the drawbacks and the poor sensitivity associated with the microscopic observation of stool samples, it remains the gold standard used by most parasitological diagnostic laboratories [104]. Depending on the microscopist's skill, diagnosis will target the presence of protozoan cysts and trophozoites, as well as microscopic identification of helminthic eggs [91]. Because there are sometimes too few eggs in samples, this tool must be replaced by other methods such as serology-based ones including ELISA (Enzyme-Linked Immunosorbent Assay) [105] and DFA (Direct Fluorescent Antibody) assays [106]. Parasitic coproculture remains a challenging technique [91], although it demonstrates good efficiency for some helminths [107] and protozoa [108,109]. Molecular approaches based on conventional PCR, Real-Time-PCR [110], PCRrestriction fragment length polymorphism (RFLP) [111] and more recently the Loop-mediated isothermal amplification (LAMP) assay [112], are alternative and promising methods for differentiating parasites [113]. Finally, next generation sequencing using pyrosequencing methods has been used to detect and genotype several protozoans $[114,115]$. However, more metagenomic and culturomic studies targeting the eukaryome are required at this time to determine the occurrence of both fungi and parasites in the human gut [91].

\section{Perspectives}

As described by Robert Koch, "a pure culture remains the foundation of all research in microbiology" [42]. The rebirth of the culture through the example of culturomics due to the efficient, cost-effective and rapid MALDI-TOF identification method opens broad perspectives for the study of complex ecosystems [42]. This revolution now largely recognized in bacterial culture is relevant for eukaryote identification [91].

However, we have a major lack of tools that can list both prokaryotes and eukaryotes isolated in humans. The recent repertoire proposed by Hugon et al. is an important first step, providing researchers and clinicians with the bacterial species associated with humans [8]. This may be implemented with eukaryotes.

Finally, this rebirth of culture highlighted a major discrepancy, that the taxonomic description is not currently adapted to this dramatic increase of new prokaryotic species [8]. Taxono-genomics has proposed for three years modification of this taxonomic classification. This new concept is based on current microbiological tools such as MALDI-TOF (spectra and comparison with the closest bacterial species) and genome sequencing (including genome comparison) to be in accordance with this reemerging field $[42,46,116]$. Moreover, the taxonomic classification remains unclear for fungi and a few explored fields for the eukaryotes. Finally, the emerging recognition of giant viruses of amoebas as inhabitants of environments and humans still expands the range of microorganisms to be characterized and enumerated from human gut, and this would involve new high-throughput strategies that have started being implemented [11]. Thinking beyond that, amoebal viruses are an incentive to readdress microbe classification [11].

\section{Acknowledgments}

We thank TradOnline (http://www.tradonline.fr/en/) and Karolina Griffiths for providing English corrections.

\section{References}

[1] J.R. Marchesi, D.H. Adams, F. Fava, G.D. Hermes, G.M. Hirschfield, G. Hold, et al., The gut microbiota and host health: a new clinical frontier, Gut (2015), http://dx.doi.org/10.1136/gutjnl-2015-309990. PubMed PMID: 26338727.

[2] R.E. Ley, P.J. Turnbaugh, S. Klein, J.I. Gordon, Microbial ecology: human gut microbes associated with obesity, Nature 444 (7122) (2006) 1022-1023, http://dx.doi.org/10.1038/4441022a. PubMed PMID: 17183309.

[3] Q. Li, C. Wang, C. Tang, N. Li, J. Li, Molecular-phylogenetic characterization of the microbiota in ulcerated and non-ulcerated regions in the patients with Crohn's disease, PloS One 7 (4) (2012) e34939, http://dx.doi.org/10.1371/ journal.pone.0034939. PubMed PMID: 22529960; PubMed Central PMCID: PMCPMC3329531.

[4] E. Malinen, L. Krogius-Kurikka, A. Lyra, J. Nikkila, A. Jaaskelainen, T. Rinttila, et al., Association of symptoms with gastrointestinal microbiota in irritable bowel syndrome, World J. Gastroenterol. WJG 16 (36) (2010) 4532-4540. PubMed PMID: 20857523; PubMed Central PMCID: PMCPMC2945484.

[5] J.C. Lagier, M. Million, P. Hugon, F. Armougom, D. Raoult, Human gut microbiota: repertoire and variations, Front. Cell. Infect. Microbiol. 2 (2012) 136, http://dx.doi.org/10.3389/fcimb.2012.00136. Epub 2012/11/07; PubMed PMID: 23130351; PubMed Central PMCID: PMC3487222.

[6] M.J. Claesson, S. Cusack, O. O'Sullivan, R. Greene-Diniz, H. de Weerd, E. Flannery, et al., Composition, variability, and temporal stability of the intestinal microbiota of the elderly, Proc. Natl. Acad. Sci. U. S. A. 108 (Suppl. 1) (2011) 4586-4591, http://dx.doi.org/10.1073/pnas.1000097107. Epub 2010/ 06/24; PubMed PMID: 20571116; PubMed Central PMCID: PMC3063589.

[7] A. Sullivan, C. Edlund, C.E. Nord, Effect of antimicrobial agents on the ecological balance of human microflora, Lancet Infect. Dis. 1 (2) (2001) 101-114, http://dx.doi.org/10.1016/S1473-3099(01)00066-4. Epub 2002/03/ 02; PubMed PMID: 11871461.

[8] P. Hugon, J.C. Dufour, P. Colson, P.E. Fournier, K. Sallah, D. Raoult, A comprehensive repertoire of prokaryotic species identified in human beings, Lancet Infect. Dis. 15 (10) (2015) 1211-1219, http://dx.doi.org/10.1016/ S1473-3099(15)00293-5. PubMed PMID: 26311042.

[9] M. Boyer, M.A. Madoui, G. Gimenez, B. La Scola, D. Raoult, Phylogenetic and phyletic studies of informational genes in genomes highlight existence of a 4 domain of life including giant viruses, PloS One 5 (12) (2010) e15530, http:// dx.doi.org/10.1371/journal.pone.0015530. PubMed PMID: 21151962; PubMed Central PMCID: PMCPMC2996410.

[10] D. Raoult, TRUC or the need for a new microbial classification, Intervirology 56 (6) (2013) 349-353, http://dx.doi.org/10.1159/000354269. PubMed PMID: 23867259.

[11] D. Raoult, How the virophage compels the need to readdress the classification of microbes, Virology 477 (2015) 119-124, http://dx.doi.org/10.1016/ j.virol.2014.11.014. PubMed PMID: 25497204.

[12] J. Gossling, J.M. Slack, Predominant gram-positive bacteria in human feces: numbers, variety, and persistence, Infect. Immun. 9 (4) (1974) 719-729. PubMed PMID: 4595760; PubMed Central PMCID: PMCPMC414872.

[13] L.J. Mata, C. Carrillo, E. Villatoro, Fecal microflora in health persons in a preindustrial region, Appl. Microbiol. 17 (4) (1969) 596-602. PubMed PMID: 4890749; PubMed Central PMCID: PMCPMC377749.

[14] W.E. Moore, L.V. Holdeman, Human fecal flora: the normal flora of 20 Japanese-Hawaiians, Appl. Microbiol. 27 (5) (1974) 961-979. PubMed PMID: 
4598229; PubMed Central PMCID: PMCPMC380185.

[15] J.T. Staley, A. Konopka, Measurement of in situ activities of nonphotosynthetic microorganisms in aquatic and terrestrial habitats, Annu. Rev. Microbiol. 39 (1985) 321-346, http://dx.doi.org/10.1146/annurev.mi.39.100185.001541. Epub 1985/01/01; PubMed PMID: 3904603.

[16] S.R. Vartoukian, R.M. Palmer, W.G. Wade, Strategies for culture of 'unculturable' bacteria, FEMS Microbiol. Lett. 309 (1) (2010) 1-7, http://dx.doi.org/ 10.1111/j.1574-6968.2010.02000.x. PubMed PMID: 20487025.

[17] P.M. Nottingham, R.E. Hungate, Methanogenic fermentation of benzoate, J. Bacteriol. 98 (3) (1969) 1170-1172. Epub 1969/06/01. PubMed PMID: 5788702; PubMed Central PMCID: PMC315310.

[18] S.M. Finegold, V.L. Sutter, P.T. Sugihara, H.A. Elder, S.M. Lehmann, R.L. Phillips, Fecal microbial flora in seventh day adventist populations and control subjects, Am. J. Clin. Nutr. 30 (11) (1977) 1781-1792. Epub 1977/11/ 01. PubMed PMID: 920638.

[19] C. Ash, J.A. Farrow, M. Dorsch, E. Stackebrandt, M.D. Collins, Comparative analysis of Bacillus anthracis, Bacillus cereus, and related species on the basis of reverse transcriptase sequencing of 16S rRNA, Int. J. Syst. Bacteriol. 41 (3) (1991) 343-346, http://dx.doi.org/10.1099/00207713-41-3-343. Epub 1991/ 07/01: PubMed PMID: 1715736.

[20] J. Chen, X. Miao, M. Xu, J. He, Y. Xie, X. Wu, et al., Intra-genomic heterogeneity in 16S rRNA genes in strictly anaerobic clinical isolates from periodontal abscesses, PloS One 10 (6) (2015) e0130265, http://dx.doi.org/ 10.1371/journal.pone.0130265. Epub 2015/06/24; PubMed PMID: 26103050; PubMed Central PMCID: PMC4477887.

[21] N.A. Kennedy, A.W. Walker, S.H. Berry, S.H. Duncan, F.M. Farquarson, P. Louis, et al., The impact of different DNA extraction kits and laboratories upon the assessment of human gut microbiota composition by 16S rRNA gene sequencing, PloS One 9 (2) (2014) e88982, http://dx.doi.org/10.1371/journal.pone.0088982. Epub 2014/03/04; PubMed PMID: 24586470; PubMed Central PMCID: PMC3933346.

[22] A.W. Walker, J.C. Martin, P. Scott, J. Parkhill, H.J. Flint, K.P. Scott, 16S rRNA gene-based profiling of the human infant gut microbiota is strongly influenced by sample processing and PCR primer choice, Microbiome 3 (2015) 26, http://dx.doi.org/10.1186/s40168-015-0087-4. Epub 2015/06/30; PubMed PMID: 26120470; PubMed Central PMCID: PMC4482049.

23] M.J. Claesson, Q Wang, O. O'Sullivan, R. Greene-Diniz, J.R. Cole, R.P. Ross, et al., Comparison of two next-generation sequencing technologies for resolving highly complex microbiota composition using tandem variable $16 \mathrm{~S}$ rRNA gene regions, Nucleic Acids Res. 38 (22) (2010) e200, http://dx.doi.org/ 10.1093/nar/gkq873. Epub 2010/10/01; PubMed PMID: 20880993; PubMed Central PMCID: PMC3001100.

[24] J.C. Lagier, F. Armougom, M. Million, P. Hugon, I. Pagnier, C. Robert, et al. Microbial culturomics: paradigm shift in the human gut microbiome study, Clin. Microbiol. Infect. Off. Publ. Eur. Soc. Clin. Microbiol. Infect. Dis. 18 (12) (2012) 1185-1193, http://dx.doi.org/10.1111/1469-0691.12023. Epub 2012/ 10/05; PubMed PMID: 23033984

[25] P. Hugon, J.C. Lagier, C. Robert, C. Lepolard, L. Papazian, D. Musso, et al. Molecular studies neglect apparently gram-negative populations in the human gut microbiota, J. Clin. Microbiol. 51 (10) (2013) 3286-3293, http:// dx.doi.org/10.1128/JCM.00473-13. Epub 2013/07/26; PubMed PMID: 23885002; PubMed Central PMCID: PMC3811629.

[26] M. Rajilic-Stojanovic, W.M. de Vos, The first 1000 cultured species of the human gastrointestinal microbiota, FEMS Microbiol. Rev. 38 (5) (2014) 996-1047, http://dx.doi.org/10.1111/1574-6976.12075. Epub 2014/05/28; PubMed PMID: 24861948; PubMed Central PMCID: PMC4262072.

[27] T. Kuehbacher, A. Rehman, P. Lepage, S. Hellmig, U.R. Folsch, S. Schreiber, et al., Intestinal TM7 bacterial phylogenies in active inflammatory bowel disease, J. Med. Microbiol. 57 (Pt 12) (2008) 1569-1576, http://dx.doi.org/ 10.1099/jmm.0.47719-0. PubMed PMID: 19018031.

[28] S.C. Di Rienzi, I. Sharon, K.C. Wrighton, O. Koren, L.A. Hug, B.C. Thomas, et al., The human gut and groundwater harbor non-photosynthetic bacteria belonging to a new candidate phylum sibling to cyanobacteria, Elife 2 (2013) e01102, http://dx.doi.org/10.7554/eLife.01102. ARTN; PubMed PMID: WOS: 000328635200002

[29] A.F. Andersson, M. Lindberg, H. Jakobsson, F. Backhed, P. Nyren, L. Engstrand, Comparative analysis of human gut microbiota by barcoded pyrosequencing, PloS One 3 (7) (2008) e2836, http://dx.doi.org/10.1371/journal.pone.0002836. PubMed PMID: 18665274; PubMed Central PMCID: PMCPMC2475661.

[30] M. Arumugam, J. Raes, E. Pelletier, D. Le Paslier, T. Yamada, D.R. Mende, et al., Enterotypes of the human gut microbiome, Nature 473 (7346) (2011) 174-180, http://dx.doi.org/10.1038/nature09944. PubMed PMID: 21508958; PubMed Central PMCID: PMCPMC3728647.

[31] M.J. Claesson, O. O’Sullivan, Q. Wang, J. Nikkila, J.R. Marchesi, H. Smidt, et al., Comparative analysis of pyrosequencing and a phylogenetic microarray for exploring microbial community structures in the human distal intestine, PloS One 4 (8) (2009) e6669, http://dx.doi.org/10.1371/journal.pone.0006669. PubMed PMID: 19693277; PubMed Central PMCID: PMCPMC2725325.

[32] Y.D. Nam, M.J. Jung, S.W. Roh, M.S. Kim, J.W. Bae, Comparative analysis of Korean human gut microbiota by barcoded pyrosequencing, PloS One 6 (7) (2011) e22109, http://dx.doi.org/10.1371/journal.pone.0022109. PubMed PMID: 21829445; PubMed Central PMCID: PMCPMC3146482.

[33] M.L. Zupancic, B.L. Cantarel, Z. Liu, E.F. Drabek, K.A. Ryan, S. Cirimotich, et al.,
Analysis of the gut microbiota in the old order Amish and its relation to the metabolic syndrome, PloS One 7 (8) (2012) e43052, http://dx.doi.org/ 10.1371/journal.pone.0043052. PubMed PMID: 22905200; PubMed Central PMCID: PMCPMC3419686.

[34] P.B. Eckburg, E.M. Bik, C.N. Bernstein, E. Purdom, L. Dethlefsen, M. Sargent, et al. Diversity of the human intestinal microbial flora, Science 308 (5728) (2005) 1635-1638, http://dx.doi.org/10.1126/science.1110591. PubMed PMID: 15831718; PubMed Central PMCID: PMCPMC1395357.

[35] S.R. Gill, M. Pop, R.T. Deboy, P.B. Eckburg, P.J. Turnbaugh, B.S. Samuel, et al., Metagenomic analysis of the human distal gut microbiome, Science 312 (5778) (2006) 1355-1359, http://dx.doi.org/10.1126/science.1124234. PubMed PMID: 16741115; PubMed Central PMCID: PMCPMC3027896.

[36] M. Murri, I. Leiva, J.M. Gomez-Zumaquero, F.J. Tinahones, F. Cardona, F. Soriguer, et al., Gut microbiota in children with type 1 diabetes differs from that in healthy children: a case-control study, BMC Med. 11 (2013) 46, http:// dx.doi.org/10.1186/1741-7015-11-46. PubMed PMID: 23433344; PubMed Central PMCID: PMCPMC3621820.

[37] J. Qin, Y. Li, Z. Cai, S. Li, J. Zhu, F. Zhang, et al., A metagenome-wide association study of gut microbiota in type 2 diabetes, Nature 490 (7418) (2012) 55-60, http://dx.doi.org/10.1038/nature11450. PubMed PMID: 23023125.

[38] T. Wang, G. Cai, Y. Qiu, N. Fei, M. Zhang, X. Pang, et al., Structural segregation of gut microbiota between colorectal cancer patients and healthy volunteers, ISME J. 6 (2) (2012) 320-329, http://dx.doi.org/10.1038/ismej.2011.109. PubMed PMID: 21850056; PubMed Central PMCID: PMCPMC3260502.

[39] H.M. Hamer, D. Jonkers, K. Venema, S. Vanhoutvin, F.J. Troost, R.J. Brummer Review article: the role of butyrate on colonic function, Aliment. Pharmacol. Ther. 27 (2) (2008) 104-119, http://dx.doi.org/10.1111/j.13652036.2007.03562.x. PubMed PMID: 17973645.

[40] R.M. Satokari, E.E. Vaughan, A.D. Akkermans, M. Saarela, W.M. de Vos, Bifidobacterial diversity in human feces detected by genus-specific PCR and denaturing gradient gel electrophoresis, Appl. Environ. Microbiol. 67 (2) (2001) 504-513, http://dx.doi.org/10.1128/AEM.67.2.504-513.2001. PubMed PMID: 11157210; PubMed Central PMCID: PMCPMC92614.

[41] P. Seng, C. Abat, J.M. Rolain, P. Colson, J.C. Lagier, F. Gouriet, et al., Identification of rare pathogenic bacteria in a clinical microbiology laboratory: impact of matrix-assisted laser desorption ionization-time of flight mass spectrometry, J. Clin. Microbiol. 51 (7) (2013) 2182-2194, http://dx.doi.org/ 10.1128/JCM.00492-13. PubMed PMID: 23637301; PubMed Central PMCID: PMCPMC3697718.

[42] J.C. Lagier, P. Hugon, S. Khelaifia, P.E. Fournier, B. La Scola, D. Raoult, The rebirth of culture in microbiology through the example of culturomics to study human gut microbiota, Clin. Microbiol. Rev. 28 (1) (2015) 237-264 http://dx.doi.org/10.1128/CMR.00014-14. Epub 2015/01/091; PubMed PMID 25567229; PubMed Central PMCID: PMC4284300.

[43] G. Dubourg, J.C. Lagier, F. Armougom, C. Robert, I. Hamad, P. Brouqui, et al., The gut microbiota of a patient with resistant tuberculosis is more comprehensively studied by culturomics than by metagenomics, Eur. J. Clin. Microbiol. Infect. Dis. Off. Publ. Eur. Soc. Clin. Microbiol. 32 (5) (2013) 637-645, http://dx.doi.org/10.1007/s10096-012-1787-3. Epub 2013/01/081 PubMed PMID: 23291779.

[44] G. Dubourg J.C. Lagier, C. Robert, F. Armougom, P. Hugon, S. Metidji, et al. Culturomics and pyrosequencing evidence of the reduction in gut microbiota diversity in patients with broad-spectrum antibiotics, Int. J. Antimicrob. Agents 44 (2) (2014) 117-124, http://dx.doi.org/10.1016/j.ijantimicag.2014.04.020. Epub 2014/07/27; PubMed PMID: 25063078.

[45] A. Pfleiderer, J.C. Lagier, F. Armougom, C. Robert, B. Vialettes, D. Raoult Culturomics identified 11 new bacterial species from a single anorexia nervosa stool sample, Eur. J. Clin. Microbiol. Infect. Dis. Off. Publ. Eur. Soc. Clin. Microbiol. 32 (11) (2013) 1471-1481, http://dx.doi.org/10.1007/ s10096-013-1900-2. Epub 2013/06/04; PubMed PMID: 23728738.

[46] D. Ramasamy, A.K. Mishra, J.C. Lagier, R. Padhmanabhan, M. Rossi, E. Sentausa, et al., A polyphasic strategy incorporating genomic data for the taxonomic description of novel bacterial species, Int. J. Syst. Evol. Microbiol. 64 (Pt 2) (2014) 384-391, http://dx.doi.org/10.1099/ijs.0.057091-0. PubMed PMID: 24505076.

[47] A.G. Oren, G.M. Garrity, Validation list $N^{\circ} 153$, Int. J. Syst. Evol. Microbiol. 63 (2013) 4.

[48] A.G. Oren, G.M. Garrity, Validation list №155, Int. J. Syst. Evol. Microbiol. 64 (2014) 5.

[49] A.G. Oren, G.M. Garrity, Validation list №165, Int. J. Syst. Evol. Microbiol. 65 (2015) 7

[50] C.R. Woese, O. Kandler, M.L. Wheelis, Towards a natural system of organisms: proposal for the domains archaea, bacteria, and eucarya, Proc. Nat Acad. Sci. U. S. A. 87 (12) (1990) 4576-4579. Epub 1990/06/01. PubMed PMID: 2112744; PubMed Central PMCID: PMC54159.

[51] S.L. Pereira, J.N. Reeve, Histones and nucleosomes in archaea and eukarya: comparative analysis, Extrem. Life Under Extrem. Cond. 2 (3) (1998) 141-148. Epub 1998/10/23. PubMed PMID: 9783158

[52] E.F. DeLong, N.R. Pace, Environmental diversity of bacteria and archaea, Syst. Biol. 50 (4) (2001) 470-478. Epub 2002/07/16. PubMed PMID: 12116647.

[53] E.F. DeLong, Everything in moderation: archaea as 'non-extremophiles', Curr. Opin. Genet. Dev. 8 (6) (1998) 649-654. Epub 1999/01/23. PubMed PMID 9914204.

[54] T.L. Miller, M.J. Wolin, Methanogens in human and animal intestinal tracts Syst. Appl. Microbiol. 7 (2-3) (1986) 223-229. PubMed PMID: WOS 
A1986C607200010.

[55] N. Gaci, G. Borrel, W. Tottey, P.W. O'Toole, J.F. Brugere, Archaea and the human gut: new beginning of an old story, World J. Gastroenterol. WJG 20 (43) (2014) 16062-16078, http://dx.doi.org/10.3748/wjg.v20.i43.16062. Epub 2014/12/05; PubMed PMID: 25473158; PubMed Central PMCID: PMC4239492.

[56] P.M. Nottingham, R.E. Hungate, Isolation of methanogenic bacteria from feces of man, J. Bacteriol. 96 (6) (1968) 2178-2179. Epub 1968/12/01 PubMed PMID: 4881707; PubMed Central PMCID: PMC252579.

[57] B. Dridi, M. Henry, A. El Khechine, D. Raoult, M. Drancourt, High prevalence of Methanobrevibacter smithii and Methanosphaera stadtmanae detected in the human gut using an improved DNA detection protocol, PloS One 4 (9) (2009) e7063, http://dx.doi.org/10.1371/journal.pone.0007063. Epub 2009/ 09/18; PubMed PMID: 19759898; PubMed Central PMCID: PMC2738942.

[58] T.L. Miller, M.J. Wolin, Methanosphaera-stadtmaniae gen-Nov, sp-Nov - a species that forms methane by reducing methanol with hydrogen, Arch Microbiol. 141 (2) (1985) 116-122, http://dx.doi.org/10.1007/Bf00423270. PubMed PMID: WOS: A1985AHM2800003.

[59] B. Dridi, M.L. Fardeau, B. Ollivier, D. Raoult, M. Drancourt, Methanomassiliicoccus luminyensis gen. Nov., sp. Nov., a methanogenic archaeon isolated from human faeces, Int. J. Syst. Evol. Microbiol. 62 (Pt 8) (2012) 1902-1907, http://dx.doi.org/10.1099/ijs.0.033712-0. Epub 2012/08/04 PubMed PMID: 22859731.

[60] A. Ferrari, T. Brusa, A. Rutili, E. Canzi, B. Biavati, Isolation and characterization of Methanobrevibacter-oralis sp-Nov, Curr. Microbiol. 29 (1) (1994) 7-12 http://dx.doi.org/10.1007/Bf01570184. PubMed PMID: WOS: A1994NM21600002.

[61] S. Khelaifia, M. Garibal, C. Robert, D. Raoult, M. Drancourt, Draft genome sequencing of Methanobrevibacter oralis strain JMR01, isolated from the human intestinal microbiota, Genome Announc. 2 (1) (2014), http:/ dx.doi.org/10.1128/genomeA.00073-14. Epub 2014/02/22; PubMed PMID: 24558239; PubMed Central PMCID: PMC3931360.

[62] G. Borrel, H.M. Harris, W. Tottey, A. Mihajlovski, N. Parisot, E. Peyretaillade, et al., Genome sequence of "Candidatus Methanomethylophilus alvus" Mx1201, a methanogenic archaeon from the human gut belonging to a seventh order of methanogens, J. Bacteriol. 194 (24) (2012) 6944-6945, http://dx.doi.org/ 10.1128/JB.01867-12. Epub 2012/12/05; PubMed PMID: 23209209; PubMed Central PMCID: PMC3510639.

[63] G. Borrel, H.M. Harris, N. Parisot, N. Gaci, W. Tottey, A. Mihajlovski, et al. Genome sequence of "Candidatus Methanomassiliicoccus intestinalis" issoire-Mx1, a third thermoplasmatales-related methanogenic archaeon from human feces, Genome Announc. 1 (4) (2013), http://dx.doi.org/ 10.1128/genomeA.00453-13. Epub 2013/07/13; PubMed PMID: 23846268; PubMed Central PMCID: PMC3709145.

[64] S. Khelaifia, M. Garibal, C. Robert, D. Raoult, M. Drancourt, Draft genome sequence of a human-associated isolate of Methanobrevibacter arboriphilicus, the lowest-G+C-content archaeon, Genome Announc. 2 (1) (2014) http://dx.doi.org/10.1128/genomeA.01181-13. Epub 2014/01/25; PubMed PMID: 24459264; PubMed Central PMCID: PMC3900896.

[65] Y.D. Nam, H.W. Chang, K.H. Kim, S.W. Roh, M.S. Kim, M.J. Jung, et al., Bacterial, archaeal, and eukaryal diversity in the intestines of Korean people J. Microbiol. 46 (5) (2008) 491-501, http://dx.doi.org/10.1007/s12275-0080199-7. Epub 2008/11/01; PubMed PMID: 18974948.

[66] M. Breitbart, I. Hewson, B. Felts, J.M. Mahaffy, J. Nulton, P. Salamon, et al. Metagenomic analyses of an uncultured viral community from human feces, J. Bacteriol. 185 (20) (2003) 6220-6223. PubMed PMID: 14526037; PubMed Central PMCID: PMCPMC225035.

[67] L.A. Ogilvie, B.V. Jones, The human gut virome: a multifaceted majority, Front. Microbiol. 6 (2015) 918, http://dx.doi.org/10.3389/fmicb.2015.00918. Epub 2015/10/07; PubMed PMID: 26441861; PubMed Central PMCID PMC4566309.

[68] E. Scarpellini, G. Ianiro, F. Attili, C. Bassanelli, A. De Santis, A. Gasbarrini, The human gut microbiota and virome: potential therapeutic implications, Dig. Liver Dis. Off. J. Ital. Soc. Gastroenterol. Ital. Assoc. Study Liver (2015), http:/| dx.doi.org/10.1016/j.dld.2015.07.008. Epub 2015/08/11; PubMed PMID: 26257129

[69] D. Raoult, P. Forterre, Redefining viruses: lessons from mimivirus, Nat. Rev. Microbiol. 6 (4) (2008) 315-319, http://dx.doi.org/10.1038/nrmicro1858. PubMed PMID: 18311164.

[70] A. Foca, M.C. Liberto, A. Quirino, N. Marascio, E. Zicca, G. Pavia, Gut inflammation and immunity: what is the role of the human gut virome? Mediat Inflamm. 2015 (2015) 326032, http://dx.doi.org/10.1155/2015/326032. Epub 2015/05/07l; PubMed PMID: 25944980; PubMed Central PMCID PMC4405218.

[71] S. Minot, A. Bryson, C. Chehoud, G.D. Wu, J.D. Lewis, F.D. Bushman, Rapid evolution of the human gut virome, Proc. Natl. Acad. Sci. U. S. A. 110 (30) (2013) 12450-12455, http://dx.doi.org/10.1073/pnas.1300833110. Epub 2013/07/10; PubMed PMID: 23836644; PubMed Central PMCID: PMC3725073.

[72] T. Zhang, M. Breitbart, W.H. Lee, J.Q. Run, C.L. Wei, S.W. Soh, et al., RNA viral community in human feces: prevalence of plant pathogenic viruses, PLoS Biol. 4 (1) (2006) e3, http://dx.doi.org/10.1371/journal.pbio.0040003. Epub 2005/12/13; PubMed PMID: 16336043; PubMed Central PMCID: PMC1310650.

[73] L.A. Ogilvie, L.D. Bowler, J. Caplin, C. Dedi, D. Diston, E. Cheek, et al., Genome signature-based dissection of human gut metagenomes to extract subliminal viral sequences, Nat. Commun. 4 (2013) 2420, http://dx.doi.org/10.1038/ ncomms3420. Epub 2013/09/17; PubMed PMID: 24036533; PubMed Central PMCID: PMC3778543.

[74] A. Reyes, M. Haynes, N. Hanson, F.E. Angly, A.C. Heath, F. Rohwer, et al., Viruses in the faecal microbiota of monozygotic twins and their mothers, Nature 466 (7304) (2010) 334-338, http://dx.doi.org/10.1038/nature09199. Epub 2010/07/16; PubMed PMID: 20631792; PubMed Central PMCID: PMC2919852.

[75] A. Reyes, N.P. Semenkovich, K. Whiteson, F. Rohwer, J.I. Gordon, Going viral: next-generation sequencing applied to phage populations in the human gut, Nat. Rev. Microbiol. 10 (9) (2012) 607-617, http://dx.doi.org/10.1038/ nrmicro2853. Epub 2012/08/07; PubMed PMID: 22864264; PubMed Central PMCID: PMC3596094

[76] A. Gorski, B. Weber-Dabrowska, The potential role of endogenous bacteriophages in controlling invading pathogens, Cell. Mol. Life Sci. CMLS 62 (5) (2005) 511-519, http://dx.doi.org/10.1007/s00018-004-4403-6. Epub 2005/ 03/05; PubMed PMID: 15747058.

[77] E.J. Klein, D.R. Boster, J.R. Stapp, J.G. Wells, X. Qin, C.R. Clausen, et al., Diarrhea etiology in a Children's Hospital Emergency Department: a prospective cohort study, Clin. Infect. Dis. 43 (7) (2006) 807-813, http://dx.doi.org/ 10.1086/507335. PubMed PMID: 16941358.

[78] C.A. Suttle, Viruses in the sea, Nature 437 (7057) (2005) 356-361, http:/ dx.doi.org/10.1038/nature04160. Epub 2005/09/16; PubMed PMID: 16163346.

[79] A. Stern, E. Mick, I. Tirosh, O. Sagy, R. Sorek, CRISPR targeting reveals a reservoir of common phages associated with the human gut microbiome, Genome Res. 22 (10) (2012) 1985-1994, http://dx.doi.org/10.1101/ gr.138297.112. Epub 2012/06/27; PubMed PMID: 22732228; PubMed Central PMCID: PMC3460193.

[80] B. La Scola, S. Audic, C. Robert, L. Jungang, X. de Lamballerie, M. Drancourt, et al., A giant virus in amoebae, Science 299 (5615) (2003) 2033, http:// dx.doi.org/10.1126/science.1081867. PubMed PMID: 12663918.

[81] M. Legendre, A. Lartigue, L. Bertaux, S. Jeudy, J. Bartoli, M. Lescot, et al., Indepth study of Mollivirus sibericum, a new 30,000-y-old giant virus infecting Acanthamoeba, Proc. Natl. Acad. Sci. U. S. A. 112 (38) (2015) E5327-E5335, http://dx.doi.org/10.1073/pnas.1510795112. PubMed PMID: 26351664; PubMed Central PMCID: PMCPMC4586845.

[82] D.G. Reteno, S. Benamar, J.B. Khalil, J. Andreani, N. Armstrong, T. Klose, et al., Faustovirus, an asfarvirus-related new lineage of giant viruses infecting amoebae, J. Virol. 89 (13) (2015) 6585-6594, http://dx.doi.org/10.1128/ JVI.00115-15. PubMed PMID: 25878099; PubMed Central PMCID: PMCPMC4468488.

[83] I. Pagnier, D.G. Reteno, H. Saadi, M. Boughalmi, M. Gaia, M. Slimani, et al. A decade of improvements in Mimiviridae and Marseilleviridae isolation from amoeba, Intervirology 56 (6) (2013) 354-363, http://dx.doi.org/ 10.1159/000354556. PubMed PMID: 24157882.

[84] D. Raoult, B. La Scola, R. Birtles, The discovery and characterization of mimivirus, the largest known virus and putative pneumonia agent, Clin. Infect. Dis. 45 (1) (2007) 95-102, http://dx.doi.org/10.1086/518608. PubMed PMID: 17554709 .

[85] P. Colson, L. Fancello, G. Gimenez, F. Armougom, C. Desnues, G. Fournous, et al., Evidence of the megavirome in humans, J. Clin. Virol. 57 (3) (2013) 191-200, http://dx.doi.org/10.1016/j.jcv.2013.03.018. PubMed PMID: 23664726.

[86] M. Boyer, N. Yutin, I. Pagnier, L. Barrassi, G. Fournous, L. Espinosa, et al., Giant Marseillevirus highlights the role of amoebae as a melting pot in emergence of chimeric microorganisms, Proc. Natl. Acad. Sci. U. S. A. 106 (51) (2009) 21848-21853, http://dx.doi.org/10.1073/pnas.0911354106. PubMed PMID: 20007369; PubMed Central PMCID: PMCPMC2799887.

[87] H. Saadi, D.G. Reteno, P. Colson, S. Aherfi, P. Minodier, I. Pagnier, et al., Shan virus: a new mimivirus isolated from the stool of a Tunisian patient with pneumonia, Intervirology 56 (6) (2013) 424-429, http://dx.doi.org/10.1159/ 000354564. PubMed PMID: 24157888.

[88] B. La Scola, C. Desnues, I. Pagnier, C. Robert, L. Barrassi, G. Fournous, et al., The virophage as a unique parasite of the giant mimivirus, Nature 455 (7209) (2008) 100-104, http://dx.doi.org/10.1038/nature07218. PubMed PMID: 18690211.

[89] J. Zhou, W. Zhang, S. Yan, J. Xiao, Y. Zhang, B. Li, et al., Diversity of virophages in metagenomic data sets, J. Virol. 87 (8) (2013) 4225-4236, http:// dx.doi.org/10.1128/JVI.03398-12. PubMed PMID: 23408616; PubMed Central PMCID: PMCPMC3624350.

[90] P.D. Scanlan, J.R. Marchesi, Micro-eukaryotic diversity of the human distal gut microbiota: qualitative assessment using culture-dependent and -independent analysis of faeces, ISME J. 2 (12) (2008) 1183-1193, http:// dx.doi.org/10.1038/ismej.2008.76. Epub 2008/08/02; PubMed PMID: 18670396.

[91] I. Hamad, D. Raoult, F. Bittar, Repertory of eukaryotes (eukaryome) in the human gastrointestinal tract: taxonomy and detection methods, Parasite Immunol. (2015), http://dx.doi.org/10.1111/pim.12284. Epub 2015/10/06; PubMed PMID: 26434599.

[92] S.M. Adl, A.G. Simpson, C.E. Lane, J. Lukes, D. Bass, S.S. Bowser, et al., The revised classification of eukaryotes, J. Eukaryot. Microbiol. 59 (5) (2012) 429-493, http://dx.doi.org/10.1111/j.1550-7408.2012.00644.x. Epub 2012/ 10/02; PubMed PMID: 23020233; PubMed Central PMCID: PMC3483872. 
[93] N. Gouba, M. Drancourt, Digestive tract mycobiota: a source of infection, Med. Mal. Infect. 45 (1-2) (2015) 9-16, http://dx.doi.org/10.1016/j.medmal.2015.01.007. Epub 2015/02/17; PubMed PMID: 25684583.

[94] G. Marklein, M. Josten, U. Klanke, E. Muller, R. Horre, T. Maier, et al., Matrixassisted laser desorption ionization-time of flight mass spectrometry for fast and reliable identification of clinical yeast isolates, J. Clin. Microbiol. 47 (9) (2009) 2912-2917, http://dx.doi.org/10.1128/JCM.00389-09. Epub 2009/07/ 03; PubMed PMID: 19571014; PubMed Central PMCID: PMC2738125.

[95] C. Santos, R.R. Paterson, A. Venancio, N. Lima, Filamentous fungal characterizations by matrix-assisted laser desorption/ionization time-of-flight mass spectrometry, J. Appl. Microbiol. 108 (2) (2010) 375-385, http:// dx.doi.org/10.1111/j.1365-2672.2009.04448.x. Epub 2009/08/08; PubMed PMID: 19659699.

[96] R. Patel, MALDI-TOF MS for the diagnosis of infectious diseases, Clin. Chem. 61 (1) (2015) 100-111, http://dx.doi.org/10.1373/clinchem.2014.221770. Epub 2014/10/04; PubMed PMID: 25278500.

[97] J. Tang, I.D. Iliev, J. Brown, D.M. Underhill, V.A. Funari, Mycobiome: approaches to analysis of intestinal fungi, J. Immunol. Methods 421 (2015) 112-121, http://dx.doi.org/10.1016/j.jim.2015.04.004. Epub 2015/04/22; PubMed PMID: 25891793; PubMed Central PMCID: PMC4451377.

[98] J.J. Berman, Taxonomic Guide to Infectious Diseases: Understanding the Biologic Classes of Pathogenic Organisms, first ed., Elsevier/Academic Press, London; Waltham, MA, 2012 xvii, 355 p.

[99] N. Gouba, D. Raoult, M. Drancourt, Plant and fungal diversity in gut microbiota as revealed by molecular and culture investigations, PloS One 8 (3) (2013) e59474, http://dx.doi.org/10.1371/journal.pone.0059474. Epub 2013/ 04/05; PubMed PMID: 23555039; PubMed Central PMCID: PMC3598745.

[100] I. Hamad, C. Sokhna, D. Raoult, F. Bittar, Molecular detection of eukaryotes in a single human stool sample from Senegal, PloS One 7 (7) (2012) e40888, http://dx.doi.org/10.1371/journal.pone.0040888. Epub 2012/07/19; PubMed PMID: 22808282; PubMed Central PMCID: PMC3396631.

[101] N. Gouba, D. Raoult, M. Drancourt, Eukaryote culturomics of the gut reveals new species, PloS One 9 (9) (2014) e106994, http://dx.doi.org/10.1371/ journal.pone.0106994. Epub 2014/09/12; PubMed PMID: 25210972; PubMed Central PMCID: PMC4161381.

[102] S.M. Finegold, H.R. Attebery, V.L. Sutter, Effect of diet on human fecal flora: comparison of Japanese and American diets, Am. J. Clin. Nutr. 27 (12) (1974) 1456-1469. Epub 1974/12/01. PubMed PMID: 4432829.

[103] S. Awasthi, D.A. Bundy, L. Savioli, Helminthic infections, Bmj 327 (7412) (2003) 431-433, http://dx.doi.org/10.1136/bmj.327.7412.431. Epub 2003/ 08/23; PubMed PMID: 12933732; PubMed Central PMCID: PMC188497.

[104] I.H. McHardy, M. Wu, R. Shimizu-Cohen, M.R. Couturier, R.M. Humphries, Detection of intestinal protozoa in the clinical laboratory, J. Clin. Microbiol. 52 (3) (2014) 712-720, http://dx.doi.org/10.1128/JCM.02877-13. Epub 2013/ 11/08; PubMed PMID: 24197877; PubMed Central PMCID: PMC3957779.

[105] B.L. Ungar, Enzyme-linked immunoassay for detection of Cryptosporidium antigens in fecal specimens, J. Clin. Microbiol. 28 (11) (1990) 2491-2495.
Epub 1990/11/01. PubMed PMID: 2254426; PubMed Central PMCID: PMC268212.

[106] L.S. Garcia, R.Y. Shimizu, Evaluation of nine immunoassay kits (enzyme immunoassay and direct fluorescence) for detection of Giardia lamblia and Cryptosporidium parvum in human fecal specimens, J. Clin. Microbiol. 35 (6) (1997) 1526-1529. Epub 1997/06/01. PubMed PMID: 9163474; PubMed Central PMCID: PMC229779.

[107] Hanan Z. Rayan, Rasha H. Soliman, Nahla M. Galal, Detection of strongyloides stercoralis in fecal samples using conventional parasitological techniques and real-time PCR: a comparative study, Parasitol. United J. 5 (2012) 8.

[108] N. Sawangjaroen, R. Luke, P. Prociv, Diagnosis by faecal culture of Dientamoeba fragilis infections in Australian patients with diarrhoea, Trans. R. Soc. Trop. Med. Hyg. 87 (2) (1993) 163-165. Epub 1993/03/01. PubMed PMID: 8337717.

[109] J. Yakoob, W. Jafri, N. Jafri, R. Khan, M. Islam, M.A. Beg, et al., Irritable bowe syndrome: in search of an etiology: role of Blastocystis hominis, Am. J. Trop. Med. Hyg. 70 (4) (2004) 383-385. Epub 2004/04/22. PubMed PMID: 15100450.

[110] A.S. Bell, L.C. Ranford-Cartwright, Real-time quantitative PCR in parasitology, Trends Parasitol. 18 (8) (2002) 337-342. Epub 2002/10/17. PubMed PMID: 12380021.

[111] M. Zavvar, J. Sadraei, H. Emadi, M. Pirestani, The use of a nested PCR-RFLP technique, based on the parasite's 18S ribosomal RNA, to characterise Cryptosporidium isolates from HIV/AIDS patients, Ann. Trop. Med. Parasitol. 102 (7) (2008) 597-601, http://dx.doi.org/10.1179/136485908X311876. Epub 2008/09/27; PubMed PMID: 18817600

[112] N. Tomita, Y. Mori, H. Kanda, T. Notomi, Loop-mediated isothermal amplification (LAMP) of gene sequences and simple visual detection of products Nat. Protoc. 3 (5) (2008) 877-882, http://dx.doi.org/10.1038/nprot.2008.57. Epub 2008/05/03; PubMed PMID: 18451795.

[113] R.B. Gasser, C. Cantacessi, A. Loukas, DNA technological progress toward advanced diagnostic tools to support human hookworm control, Biotechnol. Adv. 26 (1) (2008) 35-45, http://dx.doi.org/10.1016/j.biotechadv.2007.09.003. Epub 2007/11/21; PubMed PMID: 18024057.

[114] C. Sreekumar, D.E. Hill, K.B. Miska, M.C. Vianna, L. Yan, R.L. Myers, et al., Genotyping and detection of multiple infections of Toxoplasma gondii using pyrosequencing, Int. J. Parasitol. 35 (9) (2005) 991-999, http://dx.doi.org/ 10.1016/j.ijpara.2005.03.017. Epub 2005/07/02; PubMed PMID: 15990100.

[115] C.R. Stensvold, M. Lebbad, J.J. Verweij, C. Jespersgaard, G. von SamsonHimmelstjerna, S.S. Nielsen, et al., Identification and delineation of members of the entamoeba complex by pyrosequencing, Mol. Cell. Probes 24 (6) (2010) 403-406, http://dx.doi.org/10.1016/j.mcp.2010.07.008. Epub 2010/ 08/10; PubMed PMID: 20691255.

[116] P.E.L. Fournier, J.C. Lagier, G. Dubourg, D. Raoult, From culturomics to taxonogenomics: a need to change the taxonomy of prokaryotes in clinical microbiology, Anaerobe 36 (2015) 73-78 [Epub 2015/10/27; PubMed PMID: 26514403]. 